\title{
Kerjasama Pengelolaan Perikanan Samudera Hindia \\ Dalam Rezim Indian Ocean Tuna Commission (IOTC)
}

\author{
Soni Martin Anwar ${ }^{1}$
}

\begin{abstract}
Abstrak
Negara-negara di sekitar Samudera Hindia dihadapkan pada permasalahan perikanan yaitu berupa kegiatan penangkapan Ikan Tuna secara tidak sah (illegal), tidak dilaporkan (unreported) dan tidak sesuai dengan peraturan (unregulated) atau IUU fishing. Dari tahun ke tahun jumlah penangkapan Ikan Tuna di Samudera Hindia terus mengalami peningkatan seiring dengan meningkatnya kebutuhan masyarakat dunia terhadap daging Ikan Tuna. Hal inilah yang kemudian mendorong munculnya kegiatan penangkapan ikan IUU tersebut yang tentu saja memberikan dampak negatif terhadap ketersediaan dan kelestarian Ikan Tuna itu sendiri. Perbedaan kapasitas yang dimiliki negaranegara di sekitar wilayah Samudera Hindia atau negara-negara lain yang memiliki kepentingan di wilayah tersebut dalam menanggulangi masalah IUU telah mendorong negara-negara tersebut untuk membentuk rezim kerjasama perikanan regional melalui pembentukan Indian Ocean Tuna Commission (IOTC). Kerjasama ini diharapkan mampu menyelesaikan permasalahan kegiatan penangkapan Tuna secara IUU disamping pula permasalahan lain terkait pengelolaan dan konservasi Ikan Tuna di Samudera Hindia.
\end{abstract}

Kata-kata kunci: kerjasama, rezim, perikanan tuna, IOTC, Samudera Hindia

\begin{abstract}
The countries in Indian Ocean has several fishing problems such as Illegal, Unreported and Unregulated (IUU) Tuna fishing. Year by year Tuna fishing in Indian Ocean continue increase due to the increase of Tuna meat needed by people arround the world. This condition encourage the rise of IUU fishing that give a negative impact to the availability and conservation of the Tuna fish themself. The distinction of the countries capacity in Indian Ocean and another countries that have many interest and needed in that area has encourage those countries to establish regional cooperation regime in Tuna fishing through the establishment of Indian Ocean Tuna Commission (IOTC). This cooperation is expected to solve IUU fishing and also another problems in management and conservation of Tuna Fish in Indian Ocean.
\end{abstract}

Keywords: cooperation, rezim, tuna fisheries, IOTC, Indian Ocean

\section{Pendahuluan}

Samudera Hindia merupakan salah satu dari beberapa wilayah penting penangkapan ikan tuna dunia. Apabila dibandingkan dengan Samudera Atlantik dan Samudera Pasifik, sejumlah besar penangkapan ikan tuna di Samudera Hindia dilakukan dalam wilayah yang berada di luar jurisdiksi nasional suatu negara atau berada di perairan laut bebas di wilayah samudera Hindia sehingga diperlukan upaya lebih lanjut terhadap usaha penangkapan

tersebut. Perikanan tuna sendiri merupakan salah satu komponen penting dalam keamananan pangan (food security) dan juga sebagai dasar bagi kegiatan industri yang cukup signifikan. Kegiatan perikanan tuna menimbulkan situasi yang kompleks dimana para pemangku kepentingan yang berbedabeda telah menyebabkan munculnya perbedaan aspirasi atau pemahaman terhadap masa depan keberlanjutan perikanan tuna di Samudera Hindia.

\footnotetext{
${ }^{1}$ Staf pengajar Jurusan Hubungan Internasional, FISIP Universitas Jenderal Soedirman.
} 
Ketersediaan jumlah ikan tuna di Samudera Hindia sangat melimpah, namun sama halnya dengan sumber daya hayati laut lainnya, sumber daya perikanan tuna bukan tak terbatas. Dalam beberapa wilayah perairan dunia pernah terjadi penurunan jumlah stok ikan tuna sehingga diperlukan adanya semacam kontrol melalui pembentukan sebuah rezim perikanan regional di Samudera Hindia untuk mengantisipasi terjadinya eksploitasi ikan secara berlebihan (over-exploitation). Over-exploitation muncul di antaranya akibat semakin tingginya tingkat kebutuhan masyarakat dunia terhadap produk-produk perikanan tuna baik produk segar maupun kalengan karena untuk beberapa negara,contohnya Negara Jepang, ikan tuna telah menjadi makanan pokok mereka.

Kontrol terhadap over-exploitation ikan tuna di Samudera Hindia kemudian diwujudkan melalui pembentukan sebuah rezim perikanan regional Indian Ocean Tuna Commission (IOTC). IOTC merupakan rezim perikanan di wilayah perairan Samudera Hindia yang dibentuk pada tahun 1993 melalui perjanjian IOTC yang mulai diberlakukan pada tahun 1996. Terbentuknya rezim IOTC didesak oleh semakin tingginya kebutuhan dan kepentingan negara-negara di kawasan Samudera Hindia akan adanya suatu rezim yang berfokus pada kegiatan manajemen dan konservasi perikanan tuna di kawasan tersebut. Kepentingan negara-negara untuk mendapatkan akses menuju Samudera Hindia tentu saja memberikan dampak terhadap keberlanjutan perikanan tuna di kawasan itu mengingat negara-negara tersebut memiliki tujuan yang sama yaitu dalam hal usaha pemanfaatan dan penangkapan ikan tuna di Samudera Hindia.

Kegiatan penangkapan ikan oleh negara-negara di Samudera Hindia merupakan salah satu bagian dari terwujudnya akses kepentingan negara terhadap sumber daya perikanan tuna yang memiliki nilai ekonomi cukup tinggi. Bagi beberapa negara anggota IOTC, perikanan tuna merupakan suatu kepentingan ekonomi yang vital, contohnya negara Jepang dimana mayoritas masyarakat Jepang mengkonsumsi daging ikan laut sebagai saah satu makanan pokoknya sekaligus memberikan kontribusi cukup besar bagi perekonomian nasional Jepang. Sementara bagi beberapa negara anggota IOTC lainnya, perikanan tuna masih dianggap sebagai kepentingan ekonomi level rendah-menengah.

Upaya-upaya penangkapan ikan tuna memerlukan suatu koordinasi dalam pengelolaan dan konservasi karena ikan tuna merupakan species ikan yang membutuhkan masa-masa reproduksi dan masa pertumbuhan sebelum ditangkap oleh kapal-kapal penangkap ikan tuna. Ikan tuna sendiri merupakan jenis ikan yang melakukan pergerakan atau berenang dalam jarak tempuh yang sangat jauh (highly migratory fish stocks) melintasi samudera di dunia, menembus batasbatas teritorial laut yang dimiliki oleh suatu 
negara. Fenomena ini kemudian menyebabkan suatu negara melakukan upaya pengejaran menuju lokasi kawanan ikan tuna berkumpul sehingga sering terjadi pelanggaran terhadap kedaulatan suatu negara akibat memasuki wilayah teritorial negara tersebut dalam rangka upaya pengejaran itu.

Pemanfaatan potensi perikanan tuna diiringi dengan munculnya berbagai permasalahan lainnya di antaranya adalah penangkapan ikan secara illegal, tidak dilaporkan (unreported), tidak sesuai dengan regulasi (unregulated) atau IUU-fishing; penangkapan ikan secara berlebihan (overfishing); penangkapan secara tidak sengaja (bycatch) terhadap species lain yang berhubungan dengan ikan tuna dan proses penangkapan ikan tuna seperti ikan hiu, lumbalumba, penyu laut, burung laut dan paus dimana sebagian dari species itu telah masuk ke dalam kelompok species yang terancam kepunahan; masalah degradasi lingkungan habitat ikan tuna akibat proses pembuangan limbah bahan bakar kapal penangkap ikan; pelanggaran batas-batas laut teritorial; lemahnya mekanisme monitoring, kontrol dan pengawasan lainnya yang dilakukan di dalam yurisdiksi nasional maupun di perairan laut bebas (high seas).

Bagi masyarakat internasional, kondisi ini merupakan tantangan besar dalam mewujudkan pembangunan perikanan yang berkelanjutan sehingga perlu dilakukan upaya pembentukan organisasi kerjasama perikanan regional yang bergerak dalam manajemen dan konservasi perikanan dunia seperti IOTC. Sebagai sebuah rezim perikanan regional, IOTC juga telah menyesuaikan diri dengan aturan-aturan hukum internasional di bidang perikanan yang telah ada sebelumnya di antaranya seperti UN Convention on The Law of the Sea (UNCLOS III) 1982, FAOCompliance Agreement 1993, UN Fish Stocks Agreement (UNFSA) 1995 dan FAO-Code of Conduct for Responsible Fisheries (CCRF) 1995 dalam melaksanakan langkah-langkah manajemen dan konservasi terhadap perikanan tuna guna menjamin pembangunan perikanan berkelanjutan di kawasan Samudera Hindia.

Pembangunan perikanan berkelanjutan sendiri telah ada sejak tahun 1987 dalam agenda pertemuan internasional dalam forum World Commission on Environment and Development yang menghasilkan Brundland Report. Selanjutnya pada pertemuan Rio de Janeiro yang dikenal dengan Rio Summit pada tahun 1992 dihasilkan sebuah deklarasi yaitu Agenda 21. Pada pertemuan ini diperkenalkan konsep Code of Conduct atau kode etik bagi pembangunan perikanan berkelanjutan yang berisi prinsip-prinsip dan standar internasional tentang perilaku yang bertanggungjawab dalam pengembangan praktik perikanan atau responsible fisheries.

Perjanjian selanjutnya adalah Agreement to Promote Compliance with International Conservation and Management Measures by Fishing Vessel on the High Seas atau lebih 
dikenal dengan FAO-Compliance Agreement 1993 yang menyatakan bahwa negara-negara yang memiliki armada penangkapan ikan di laut lepas diharuskan mematuhi aturan-aturan yang disepakati bersama dan negara-negara tersebut harus menyediakan dan memberikan informasi tentang kegiatan operasional armada kapal penangkap ikan milik mereka.

Berikutnya adalah UN Convention on the Law of the Sea (UNCLOS III 1982) yang mulai diberlakukan tahun 1994 yang merupakan perjanjian internasional tentang hukum laut internasional yang menuntut keseimbangan antara pemanfaatan sumber daya dengan konservasi dalam kerangka kedaulatan wilayah masing-masing negara yang ditetapkan melalui batas-batas laut teritorial.

Dalam konferensi Food and Agriculture Organization (FAO) tanggal 31 Oktober 1995, prinsip-prinsip yang dihasilkan dalam Rio Summit diadopsi menjadi kode etik perikanan yang bertanggungjawab atau yang dikenal sebagai Code of Conduct for Responsible Fisheries (CCRF). Secara prinsip kode etik tersebut merupakan dasar dan standar internasional bagi upaya konservasi, pengelolaan dan pembangunan perikanan secara keseluruhan yang meliputi beberapa wilayah pengaturan mengenai penangkapan, pengolahan, perdagangan dan hasil perikanan, operasional penangkapan (metode dan prosedur), aquakultur, penelitian perikanan dan integrasi berbagai kegiatan perikanan ke dalam pengelolaan wilayah pesisir.

Perjanjian lainnya adalah $U N$ Agreement Relating to the Conservation and Management of Stradling Fish Stocks and Highly Migratory Fish Stocks atau lebih dikenal denagan UN Fish Stocks Agreement (UNFSA 1995), sebuah perjanjian yang berisi tentang aturan-aturan dalam perikanan dan penangkapan ikan yang dilakukan baik di dalam Zona Ekonomi Eksklusif (ZEE) suatu negara maupun yang beraada di luar ZEE negara terkait dengan jenis-jenis ikan yang melakukan pergerakan atau perpindahan daam jarak yang sangat jauh (highly migratory fish stocks). Perjanjian ini juga berisi ketentuanketentuan tentang hak-hak inspeksi dan mekanisme penyelesaian masalah. Selanjutnya adalah Declaratioan on Responsible Fisheries in the Marine Ecosystem dalam pertemuan FAO atau lebih dikenal dengan Reykjavik Declaration yang berisi pernyataan janji negara-negara penandatangan deklarasi perihal tanggungjawab dan pengelolaan serta kesadaran terkait perlindungan terhadap ekosistem laut.

Terbentuknya beragam perjanjian internasional dan beragam rezim perikanan regional ini merupakan bentuk kepedulian negara-negara dan masyarakat internasional terhadap proses pengelolaan sumber daya laut khususnya perikanan tuna. Beberapa rezim perikanan regional difokuskan untuk menangani masalah pengelolaan ikan Tuna dunia yaitu The Inter-American Tropical Tuna 
Commission (IATTC), the International Commission for the Conservation of Atlantic Tunas (ICCAT), the Commission for the Conservation of Southern Bluefin Tuna (CCSBT), the Western and Central Pacific Fisheries Commission (WCPFC) dan the Indian Ocean Tuna Commission (IOTC). The Indian Ocean Tuna Commission (IOTC) merupakan salah satu rezim kerjasama perikanan regional yang dibentuk oleh FAO menjalankan fungsinya sebagai rezim yang menerapkan langkah-langkah manajemen dan konservasi dalam pengelolaan perikanan samudera Hindia.

\section{Kerangka Pemikiran}

\section{Kerjasama Internasional}

Setiap negara berusaha memenuhi kebutuhan hidup rakyatnya, oleh karena itu perlu melakukan kerjasama internasional. Kerjasama internasional mempunyai beberapa tujuan yaitu membebaskan bangsa-bangsa di dunia dari kemiskinan dan kelaparan, membebaskan bangsa-bangsa dari keterbelakangan di bidang ekonomi, memajukan perdagangan, mempercepat pertumbuhan ekonomi, meningkatkan kestabilan dalam bidang ekonomi, politik, sosial, budaya dan pertahanan keamanan,memelihara ketertiban dan perdamaian dunia, meningkatkan dan memperat tali persahabatan antarbangsa di dunia.

Kerjasama internasional memberikan wadah yang memungkinkan bagi setiap negara untuk melakukan pola hubungan internasional. Negara bisa berinteraksi secara lebih intens dengan negara lain, karena negara tersebut telah menyetujui aturan-aturan yang dianut dalam ketentuan dalam kerjasama internasional tersebut. Dengan demikian maka akan tercipta ketergantungan antar-bangsa dalam berbagai bidang, seperti perdagangan, kebudayaan, ilmu pengetahuan, dan masih banyak lagi (Kusumaatmadja \& Agoes 2003). Kerjasama internasional membuka berbagai macam kemungkinan baru bagi setiap negara untuk melakukan hubungan internasional dalam dunia global.

\section{Rezim Internasional}

Kepentingan rezim timbul karena adanya ketidakpuasan akan konsep dominan dari tata aturan internasional, kewenangan, dan organisasi (Haggard \& Simmons, 1987:491). Definisi rezim berbeda dengan definisi kerjasama terutama dengan definisi dari institusi. Rezim merupakan contoh dari perilaku kerjasama dan upaya untuk memfasilitasi kerjasama, namun kerjasama dapat terjadi tanpa adanya rezim terlebih dahulu (Haggard \& Simmons, 1987:495). Perbedaan mendasar antara rezim dengan institusi adalah cara kedua hal ini dalam memandang aktor-aktor dalam hubungan internasional terutama organisasi internasional. Rezim mengacu pada pengaruh perilaku yang ditimbulkan dari organisasi internasional pada 
aktor-aktor yang lainnya, terutama aktor negara. Rezim berfokus pada ekspektasi aktor, berbeda dengan institusi yang lebih melihat kepada apa yang terjadi dalam organisasi daripada melihat pengaruh yang ditimbulkan organisasi internasional terhadap aktor-aktor lainnya (Barkin. 2006:27).

Perbedaan utama dari rezim dengan institusi terletak pada siapa yang digolongkan menjadi aktor (Barkin, 2006:36). Institusi melihat organisasi internasional sebagai aktor dan mencermati apa yang organisasi internasional lakukan. Kontras dengan rezim yang melihat aktor yang utama adalah negara yang mana merupakan sumber yang mempengaruhi politik internasional. Norma, aturan dan prosedur dalam pembuatan keputusan itu berhubungan dengan ekspektasi dan perilaku dari negara. Pembeda antara rezim dan institusi dalam mempelajari organisasi internasional adalah jika intitusi melihat apa yang terjadi di dalam organisasi tersebut sedangkan rezim melihatnya pada perilaku negara yang mempengaruhi norma serta aturan yang dianut oleh organisasi internasional yang pada akhirnya menciptakan suatu perilaku pada organisasi tersebut (Barkin, 2006:36).

Menurut Stephen D. Krasner, rezim internasional adalah suatu tatanan yang berisi kumpulan prinsip, norma, aturan, proses pembuatan keputusan-baik bersifat eksplisit maupun implisit-yang berkaitan dengan ekspektasi atau pengharapan aktor-aktor dan memuat kepentingan aktor itu sendiri dalam hubungan Internasional.

Robert Jervis menyatakan rezim tidak hanya mempunyai implikasi terhadap normanorma yang memfasilitasi terciptanya kerjasama semata, melainkan suatu bentuk kerjasama yang lebih dari sekedar kepentingan internal dalam jangka pendek.

Keohane dan Nye mendefinisikan regime sebagai "sets of governing arrangements" yg termasuk di dalamnya "networks of rules, norms and procedures that regularized behavior and control its affects". Rezim harus dipahami sebagai sesuatu yg lebih dari sekedar arrangement sesaat yang dapat berubah oleh setiap perubahan power dan interest. Karenanya untuk keperluan analisa, harus dibedakan antara regimes dan agreement. "Agreements are ad hoc (khusus), often "one-shot" arrangement. Sehingga dapat dikatakan bahwa rezim itu memfasilitasi agreement.

\section{Metode Penelitian}

Tipe penelitian yang digunakan adalah deskriptif-analitis, dimana penulis menjelaskan dinamika kerjasama negara-negara dalam rezim kerjasama perikanan regional IOTC di wilayah Samudera Hindia melalui pelaksanaan langkah-langkah manajemen dan konservasi sumberdaya perikanan laut khususnya ikan Tuna. Data-data yang disajikan adalah datadata sekunder yang diperoleh melalui telaah pustaka dan literatur-literatur seperti buku, 
internet dan lain-lain. Teknik analisis data yang digunakan yaitu teknik analisa data kualitatif.

\section{Pembahasan}

Pemanfaatan sumberdaya laut saat ini telah mengalami peningkatan seiring dengan meningkatnya permintaan kebutuhan dalam negeri suatu negara utamanya terhadap komoditas sumberdaya ikan. Bagi beberapa negara, pemanfaatan sumberdaya perikanan merupakan modal penting bagi pembangunan ekonomi dimana dalam proses pemanfatan tersebut dibutuhkan kapasitas teknis, finansial dan sumberdaya manusia yang cukup mumpuni sehingga hasil komoditas yang diperoleh menjadi lebih maksimal. Salah satu cara untuk meningkatkan kapasitas tersebut adalah dengan membentuk kerjasama perikanan regional dimana kerjasama ini pada akhirnya akan mampu meminimalisir keterbatasan kemampuan beberapa negara dalam mencapai tujuan pembangunan di bidang perikanan serta dalam hal manajemen perikanan berkelanjutan.

Pembentukan kerjasama perikanan regional atau Regional Fishery Organization (RFO) merupakan salah satu mekanisme kerjasama antar negara di beberapa wilayah samudera. Komunitas internasional memandang bahwa pembentukan RFO merupakan suatu kebutuhan penting untuk mengelola sumber daya perikanan secara lebih rasional dan berkelanjutan. RFO merupakan organisasi tetap yang bertugas mengelola perikanan pada wilayah tertentu atau jenis species tertentu dan menggalakan eksploitasi perikanan yang lebih bertanggungjawab melalui kolaborasi banyak Negara (Sydnes, 2002). Peningkatan jumlah RFO di dunia dimulai sejak abad ke-20 dengan tujuan, ruang lingkup, batasan, cakupan dan kepentingan yang beragam (Laxe, 2008). Wilayah operasional RFO ini juga sangat bergantung pada negara-negara yang membentuknya sehingga aktivitas mereka relatif terbatas.

Terdapat beberapa klasifikasi dalam RFO berdasarkan kriteria pengelompokan tertentu. Pertama, RFO yang secara khusus dibentuk di wilayah yang spesifik, contohnya North East Atlantic Fisheries Commission (NEAFC) yang wilayah operasionalnya meliputi Samudera Atlantik bagian Timur Laut. Kedua, RFO yang dibentuk berdasarkan jenis species ikan yang ada di wilayah samudera tertentu Commission for the Conservation of Southern Bluefin Tuna (CCSBT). Ketiga, RFO yang dibentuk karena wilayah kompetensinya ditentukan oleh persyaratan umum seperti South West Indian Ocean Fisheries Commission (SWIOFC). Keempat, RFO yang dibentuk dengan wilayah kompetensi yang lebih luas bahkan melebihi wilayah kompetensi semula, contohnya GFCM yang wilayah kompetensinya berada di Mediterania sekaligus Laut Hitam. Berikut ini beberapa klasifikasi RFO berdasarkan kriteria lainnya yaitu: 
Tabel 1. RFO Berdasarkan Wilayah dan Ruang Lingkup

\begin{tabular}{|c|c|}
\hline $\begin{array}{l}\text { Wilayah dan Ru- } \\
\text { ang Lingkup }\end{array}$ & $\begin{array}{l}\text { Regional Fisheries Organization } \\
\text { (RFO) }\end{array}$ \\
\hline $\begin{array}{lll}\text { FO di bawah } \\
\text { AO }\end{array}$ & $\begin{array}{l}\text { APFIC, COPESCAL, GFCM, } \\
\text { SWIOFC, CECAF, CWP, IOTC, } \\
\text { WECAFC, CIFA, EIFAC, RECOFI }\end{array}$ \\
\hline $\begin{array}{l}\text { RFO Lintas sam- } \\
\text { udera } \\
\text { (internasional) }\end{array}$ & $\begin{array}{l}\text { ACFR, CWP, CCAMLR, IWC, } \\
\text { CCSBT, OLDEPESCA }\end{array}$ \\
\hline $\begin{array}{ll}\text { RFO Samudera } \\
\text { Atlantik }\end{array}$ & $\begin{array}{l}\text { AAFC, CECAF, ICCAT, NAM- } \\
\text { MCO, SEAFO, CARPAS, COFRE- } \\
\text { MAR, ICES, NASCO, SRFC, } \\
\text { COREP, ISBF, NAFO, NEAFC, } \\
\text { WECAFC }\end{array}$ \\
\hline $\begin{array}{ll}\text { RFO } & \text { Samudera } \\
\text { Pasifik } & \end{array}$ & $\begin{array}{l}\text { APFIC, IATTC, NPAFC, PSC, } \\
\text { CPTFA, PCSP, IPHC, NACA, SPC, } \\
\text { FFA, WCPFC, PICES, SEAFDEC }\end{array}$ \\
\hline $\begin{array}{ll}\text { RFO } & \text { Samudera } \\
\text { Hindia } & \end{array}$ & $\begin{array}{l}\text { BOBP-IGO, SWIOFC, } \\
\text { WIOTO, RECOFI }\end{array}$ \\
\hline $\begin{array}{l}\text { RFO Laut Mediter- } \\
\text { ania }\end{array}$ & GFCM \\
\hline $\begin{array}{l}\text { RFO perairan } \\
\text { Pedalaman }\end{array}$ & $\begin{array}{l}\text { APFIC, EIFAC, NACA, } \\
\text { MRC, COPESCAL, LVFO }\end{array}$ \\
\hline
\end{tabular}

Tabel 2. RFO Berdasarkan Jenis Kompetensi

\begin{tabular}{|c|c|}
\hline $\begin{array}{l}\text { Jenis Kom- } \\
\text { petensi }\end{array}$ & Regional Fisheries Organization (RFO) \\
\hline $\begin{array}{l}\text { Organisasi } \\
\text { Manajemen }\end{array}$ & $\begin{array}{l}\text { CEPTFA, ICCAT, NASCO, CCSBT, } \\
\text { IOTC, NEAFC, GFCM, IPHC,NPAFC, } \\
\text { IATTC, IWC, PSC, IBSFC, WCPFC, } \\
\text { SEAFO, NAFO, SWIOFC }\end{array}$ \\
\hline $\begin{array}{l}\text { Organisasi } \\
\text { Penasehat }\end{array}$ & $\begin{array}{l}\text { AAFC, COPESCAL, LVFO, WECAFC, } \\
\text { APFIC, COREP, NAMMCO, WITO, } \\
\text { BOBP-IGO, PCSP, MARC, SEAFDC, } \\
\text { CARPAS, COFREMAR, OLDESPESCA, } \\
\text { CECAF, EIFAC, RECOFI, CIFA, FFA, } \\
\text { SRCF }\end{array}$ \\
\hline $\begin{array}{l}\text { Organisasi } \\
\text { Ilmiah }\end{array}$ & ACFR, CWP, ICES, NACA, PICES, SPC \\
\hline
\end{tabular}

Rezim IOTC yang akan dianalisa dalam tulisan ini, berdasarkan wilayah dan ruang lingkupnya termasuk dalam wilayah Samudera Hindia. Sedangkan berdasarkan kompetensinya, IOTC tergolong ke dalam RFO yang bergerak dalam kompetensi manajemen perikanan.

\section{Kerjasama Perikanan Tuna Samudera Hindia Sebelum Dibentuknya IOTC}

Pembentukan RFO dalam pengelolaan perikanan Samudera Hindia didesak oleh semakin meningkatnya usaha penangkapan ikan tuna dan sejenis Tuna baik untuk kebutuhan konsumsi maupun industri pada tahun 1980an. Usaha penangkapan ikan Tuna dan sejenisnya meningkat dari 150.000 ton pada awal 1960an menjadi 306.905 ton pada tahun 1980, dan 566.231 ton pada tahun 1985. Usaha penangkapan berskala industri utamanya dilakukan oleh Jepang, Korea dan Taiwan (Kambona \& Marashi, 1996). Selama periode tahun-tahun ini, kapal-kapal penangkap ikan Tuna dari Komunitas Eropa atau European Community (EC) memfokuskan kegiatannya di wilayah Samudera Hindia bagian barat, utamanya negara Seychelles yang tetap dianggap menjadi pelabuhan paling penting di wilayah tersebut (Kambona \& Marashi, 1996).

Respon terhadap meningkatnya usaha-usaha penangkapan oleh banyak negara ini semakin mengemuka dan mendorong pembentukan organisasi kerjasama perikanan Tuna dengan 
struktur manajemen yang memiliki kompetensi dan rezim yang memiliki otoritas dalam menghadapi semua tantangan yang muncul akibat meningkatnya usaha penangkapan ikan di wilayah Samudera Hindia.

Usaha pembentukan kerjasama perikanan regional di Samudera Hindia telah dimulai dengan diselenggarakannya dua sidang konsultasi pemerintahan di Roma pada tahun 1987 dan di Bangkok pada tahun 1988. Sebelum usaha pembentukan organisasi tersebut, sumber daya perikanan di wilayah samudera Hindia berada di bawah pengelolaan dua badan yang dibentuk dalam naungan FAO yaitu Indian Ocean Fishery Commission (IOFC) dan the Indo-Pacific Fisheries Commission (IPFIC) (Miller, 2007). Selain itu ada organisasi ketiga yang juga beroperasi untuk melayani dan memenuhi kebutuhan dari negara-negara kepulauan kecil yaitu the Western Indian Ocean Tuna Commission (WIOTO).

\section{Proses Terbentuknya Rezim IOTC} Konstitusi FAO Pasal XIV

Semenjak kegiatan penangkapan ikan oleh negara-negara DWFN di wilayah Samudera Hindia mengalami peningkatan, usaha penangkapan ikan tuna sebagai salah satu species yang menjadi target penangkapan tentu saja juga ikut mengalami peningkatan. Sebagai respon terhadap meningkatnya kegiatan penangkapan ikan ini, maka muncul upaya-upaya untuk membentuk organisasi yang mengelola dan mengatur penangkapan ikan tuna di wilayah Samudera Hindia. Setelah menyelenggarakan serangkaian sidang konsultasi antar pemerintah, komite IOFC dalam manajemen perikanan tuna Samudera Hindia menyetujui keputusan sidang yang ke10 yang menyatakan perlu dibentuknya badan baru yang sesuai dengan ketentuan dalam pasal XIV konstitusi FAO. Dengan membentuk sebuah institusi dalam kerangka FAO, dapat dipahami bahwa badan baru itu dapat mempertahankan tingkat otonominya dan dalam waktu yang bersamaan keuntungan berupa bantuan keuangan dan teknis dapat diperoleh dari FAO.

Dukungan FAO kepada RFO sangat penting untuk meningkatkan kegiatan mereka dalam menggalakan keberlanjutan perikanan jangka panjang melalui langkah-langkah manajemen dan konservasi. Hal ini juga penting bagi pemanfaatan perikanan tuna dimana pengelolaannya membutuhkan kerjasama internasional. Usulan tentang pembentukan IOTC sudah sesuai dengan ketentuan pasal XIV konstitusi FAO. Kegiatan FAO melalui RFO seperti IOTC bertujuan untuk menggalakan kerjasama perikanan internasional guna meningkatkan manajemen dan konservasi sumber daya perikanan. Saat ini terdapat sepuluh RFO yang dibentuk berdasarkan pasal VI dan Pasal XIV konstitusi FAO. RFO yang terbentuk melalui pasal VI hanya memiliki kewajiban sebagai badan penasehat dan bergantung pada dukungan administrasi dan keuangan dari FAO, 
sementara RFO yang dibentuk berdasarkan pasal XIV lebih otonom dan dapat memberikan kewajiban-kewajiban tambahan dan mandat lainnya kepada negara-negara anggotanya terpisah dari kewajiban-kewajiban dasar yang telah diberikan oleh FAO. Salah satu contoh RFO yang dibentuk berdasarkan pasal XIV konstitusi FAO adalah APFIC yang merupakan RFO tertua di dunia. APFIC berperan sebagai badan penasehat dan memberikan petunjuk-petunjuk mengenai langkah-langkah manajemen dan petunjuk ilmiah lannya kepada para anggotanya.

FAO mendefinisikan RFO sebagai orgnisasi atau tatanan institusi perikanan antar pemerintahan yang memiliki kompetensi untuk membentuk langkah-langkah manajemen dan konservasi perikanan. FAO sendiri berkewajiban untuk mengumpulkan, menganalisa, menginterpretasikan dan menyebarluaskan informasi perihal makanan, nutrisi dan pertanian, termasuk di dalamnya produk-produk ikan dan produk laut lainnya. Di samping itu FAO juga menggalakan, bila perlu memberikan rekomendasi nasional dan internasional, terkait konservasi sumber daya alam dan pelaksanaan kebijakan internasional sesuai dengan tatanan peraturan komoditas pertanian. Karena itulah FAO mengakui peran penting yang dimainkan oleh RFO seperti IOTC dalam memperkuat kerjasama regional yang berfokus pada manajemen dan konservasi perikanan tuna. FAO memainkan peran penting dalam mendukung RFO dengan cara menghadapi issu-issu yang merintangi efektivitas RFO salah satu di antaranya yaitu kelebihan kapasitas (overcapacity).

\section{Perjanjian Pembentukan Indian Ocean Tuna Commission (IOTC)}

Kebutuhan untuk membentuk rezim pengelolaan perikanan di Samudera Hindia telah muncul pada akhir tahun 1960 dan proses untuk mewujudkan tujuan itu baru benar-benar dimulai pada tahun 1986 dan berujung pada kesepakatan untuk mendirikan Indian Ocean Tuna Commission (IOTC) oleh Dewan FAO pada tahun 1993. Pada tahun 1989, di Roma, sebuah konferensi digelar untuk menyusun naskah perjanjian dan memutuskan bahwa diperlukan penelitian dan kajian lebih lanjut perihal teks perjanjian tersebut. Kemudian menyusul amandemen dari peraturan dasar FAO di bulan November 1991, konferensi kedua diselenggarakan di Roma pada bulan Juni 1992. Konferensi ini membahas tentang klarifikasi beberapa issu atau pokok persoalan serta menghasilkan kesepakatan lebih luas terkait isi naskah perjanjian. Naskah perjanjian pada akhirnya disetujui oleh Dewan FAO pada tanggal 25 November 1993. Naskah perjanjian diedarkan untuk disetujui pada bulan Maret 1994 dan mulai diberlakukan pada tanggal 25 Maret 1996 melalui instrumen penerimaan dan persetujuan oleh Dewan FAO.

Konferensi pertama untuk menyetujui naskah perjanjian pembentukan Indian Ocean Tuna Commission (IOTC) diselenggarakan . 
pada tahun 1989 diikuti dengan pelaksanaan konferensi teknis tahun 1992. Perjanjian pembentukan IOTC disetujui pada tahun 1993, disahkan oleh IOFC tahun 1994, dan diberlakukan sejak tanggal 27 Maret 1996 sehingga IOTC dapat beroperasi secara penuh. Perjanjian IOTC memberi wewenang kepada komisi untuk menjetujui langkah-langkah manajemen dan konservasi dan juga menegaskan wilayah kompetensi dari IOTC. IOTC mewajibkan negara-negara anggota komisi untuk menjamin bahwa hukum nasional mereka akan konsisten dan tunduk kepada perjanjian yang telah disepakati.

Tujuan dari IOTC adalah menggalakan kerjasama di antara para anggotanya melalui manajemen yang sesuai, dengan visi untuk menjamin konservasi dan pemanfaatan optimal terhadap ketersediaan ikan yang diatur oleh perjanjian serta menggalakan pembangunan berkelanjutan di bidang perikanan laut berdasarkan ketersediaan cadangan ikan. Sementara fungsi dari IOTC sendiri adalah melakukan review terhadap kondisi dan informasi terkini mengenai status ketersediaan ikan, mengumpulkan dan menganalisa serta menyebarluaskan informasi ilmiah, data-data statistik dan usaha penangkapan serta data lainnya yang relevan untuk konservasi dan manajemen perikanan sesuai dengan yang terdapat dalam perjanjian.

IOTC juga berfungsi dalam mendorong, merekomendasikan dan mengkoordinasikan riset dan aktivitas pembangunan perikanan dan aktifitas IOTC lainnya dimana komisi dapat memutuskan secara tepat termasuk aktivitas yang terkait dengan transfer teknologi, pelatihan dan pemutakhiran teknologi sesuai dengan kebutuhan dan partisipasi yang seimbang dari anggota-anggota IOTC dalam pengelolaan perikanan dan kebutuhan khusus dari negaranegara di sekitar kawasan Samudera Hindia yang notabene adalah negara-negara berkembang. IOTC juga menyetujui dasar-dasar pembuktian ilmiah, konservasi dan langkah-langkah manajemen untuk menjamin konservasi terhadap species ikan yang terdapat dalam perjanjian serta meningkatkan tujuan pemanfaatan secara optimal di seluruh wilayah Samudera Hindia. Fungsi dari IOTC berikutnya adalah terus melakukan review terhadap aspek-aspek sosial ekonomi perikanan berdasarkan perjanjian, utamanya kepentingan-kepentingan negaranegara pesisir.

Sementara wilayah kompetensi dari IOTC adalah wilayah Samudera Hindia yang ditegaskan untuk tujuan pelaksanaan perjanjian serta berada dalam lingkup Statistik FAO 51 dan 57, wilayah laut yang berdekatan atau berbatasan langsung dengan Samudera Hindia, wilayah sebelah utara dari kutub selatan atau Antartika, sampai wilayah Samudera Hindia yang paling ujung selama wilayah tersebut diperlukan untuk tujuan konservasi dan manajemen ikan tuna baik yang menuju ke dalam maupun yang keluar dari wilayah perairan samudera Hindia.

Semua negara anggota dan anggota rekanan FAO dapat menjadi anggota IOTC jika mereka adalah a) negara-negara pesisir atau anggota rekanan yang sebagian atau seluruh wilayahnya berada di wilayah 
Samudera Hindia, b) negara-negara atau anggota rekanan yang kapalnya terlibat dalam proses penangkapan ikan di wilayah Samudera Hindia dan c) organisasi integrasi ekonomi regional dimana negara-negara yang ada dalam point a) dan b) merupakan anggotanya dan dimana kepadanya negara-negara tersebut juga mentransfer kompetensinya perihal masalah-masalah yang muncul dalam ruang lingkup perjanjian IOTC. Sebagai tambahan, melalui mekanisme pemungutan suara terbanyak atau dua pertiga suara dari total anggota, IOTC memperbolehkan keanggotaan negara-negara yang bukan anggota FAO tapi merupakan anggota PBB, atau yang berasal dari agen khusus, atau dari International Atomic Energy Agency (IAEA), asalkan negara -negara tersebut adalah a) negara-negara yang sebagian atau seluruh wilayahnya terletak di Samudera Hindia atau b) negara-negara yang kapalnya terlibat dalam usaha penangkapan ikan yang berada dalam ruang lingkup perjanjian IOTC .

Perjanjian IOTC di antaranya berisi tentang prosedur-prosedur mengenai permohonan keanggotaan. Semenjak FAO memainkan peran penting dalam penerimaan anggota IOTC, maka penting bagi FAO untuk menilai prosedur-prosedur penerimaan keanggotaan IOTC guna menjamin bahwa hanya calon anggota yang yang sesuai dengan ketentuan IOTC yang akan diterima sebagai anggota.

Terdapat 16 species ikan tuna dan sejenisnya yang berada di bawah manajemen IOTC. IOTC juga memerintahkan kepada sekretariat untuk mengumpulkan data perihal hasil tangkapan species lain yang bukan menjadi target penangkapan, species yang berhubungan dan bergantung pada species ikan tuna yang menjadi target penangkapan yang dipengaruhi oleh kegiatan penangkapan ikan tuna.

IOTC memainkan peranan yang sangat penting dalam memelihara keberlanjutan jangka panjang atas ketersediaan ikan Tuna di wilayah Samudera Hindia. Negara-negara anggota IOTC melalui mekanisme kerja di dalam komisi, memiliki tanggungjawab dalam mengelola dan melakukan usaha konservasi terhadap komoditas ikan tuna yang berada di dalam ruang lingkupnya. Untuk itu IOTC harus menjalankan serangkaian langkah-langkah manajemen dan konservasi yang sesuai dengan hukum internasional yang telah ada.

Pelaksanaan langkah-langkah manajemen dan konservasi merupakan hal pokok dalam kerangka kerjasama IOTC. Negara-negara melalui UN Fish Stocks Agreement memiliki kewajiban untuk saling bekerjasama dengan negara lain melalui Regional Fisheries Organization (RFO) dalam rangka menjalankan langkah-langkah guna menjamin keberlanjutan jangka panjang atas ketersediaan ikan tuna dan meningkatkan tujuan pemanfaatan secara optimum. 
Negara-negara juga harus setuju dan patuh terhadap langkah-langkah itu. Pelaksanaan beberapa langkah manajemen tersebut juga difasilitasi melalui prosedurprosedur pengambilan keputusan dalam IOTC. Kewajiban ini telah konsisten dengan ketentuan-ketentuan yang ada dalam UN LOSC dan UN Fish Stocks Agreement. Pelaksanaan langkah-langkah manajemen dan konservasi dalam IOTC di antaranya melalui ppendekatan dalam ,manajemen species Tuna yang menjadi target, status species yang menjadi target, manajemen kapasitas dan usaha penangkapan Ikan Tuna, penentuan batasan jumlah tangkapan, pendekatan konservasi species non-target .

\section{Kesimpulan}

Kepentingan ekonomi suatu negara telah mendorong negara memaksimalkan upaya dalam memenuhi dan meningkatkan kebutuhan warga negaranya. Upaya ini salah satunya diwujudkan melalui pembentukan kerjasama regional di bidang perikanan Tuna di wilayah Samudera Hindia yang diperkuat melalui pembentukan rezim IOTC. Negaranegara yang berada di wilayah Samudera Hindia berusaha memanfaatkan sumberdaya laut yang berada di laut bebas pada perairan Samudera Hindia. Demikian pula negaranegara yang letaknya sangat jauh dari kawasan perairan ini juga berusaha memperoleh manfaat yang sama, melalui keanggotaannya dalam IOTC. Upaya untuk mengakomodasi berbagai kepentingan yang dimiliki negara-negara dan stakeholders lainnya di wilayah Samudera Hindia tentu saja harus diperkuat melalui pembentukan rezim IOTC, mengingat bahwa pemanfaatan sumber daya laut tidak terlepas dari permasalahan kedaulatan wilayah laut sebuah negara karena sifat biologis dari ikan Tuna yang melakukan pergerakan atau migrasi jarak jauh dan melintasi banyak wilayah teritorial negaranegara. 


\section{Daftar Pustaka}

Acharya, Amitav, and Alastair Iain Johnston, 2007. Crafting Cooperation, Regional International Institutions in Comparative Perspective. New York: Cambridge University Press.

Allen, Robin, James Joseph, dan Dale Squires(ed), 2010. Conservation and Management of Transnational Tuna Fisheries. Iowa: Blackwell Publishing.

Are K. Sydnes, 2002. Regional Fishery Organizations in Developing Regions: Adapting to Changes in International Fisheries Law, Marine Policy

Feidi,Izzat, 2002. Post Evaluation Study of the Indian Ocean Fisheri Commission : Committee for Development and Management of the Fishery Resources of the Gulfs, FAO Fisheries Circular

Hasenclever, Andreas, Peter Mayer, dan Volker Rittberger, 1997. Theories of International Regimes, Cambridge Studies in International Relations. New York: Cambridge University Press.

Kambona, J.J and S.H. Marashi, 1996. Process for The Establishment of The Indian Ocean Tuna Comission, FAO fisheries circular No. 913

Keohane, Robert, 1984. After Hegemony: Cooperation and discord in the world Political Economy. Princeton University Press.

Keohane, Robert O, and Joseph S. Nye, Power and Interdependence . Boston: Little, Brown.

Krasner, Stephen D., 1983. International Regimes. Ithaca, New York: Cornell University Press.

Kusumaatmadja, Mochtar dan Etty R. Agoes. 2003. Pengantar Hukum Internasional. Jakarta. Alumni Laxe, F. Gonzalez, 2008. Territorialisation Processes in Fisheries Management, Ocean and Coastal Management

Marashi,S.M., 1996. Summary Information on the Role of International Fishery and other Bodies with Regard to the Conservation and Management of Living Resources of the High Seas, FAO Fisheries Circular

Menasveta, Deb, 1998. APFIC: Its Evolution, Achievements and Future Direction . 50th Anniversary-Asia-Pacific Fishery Commission.

Miller, Kathleen A., 2007. Climate Variability and Tropical Tuna: Management Challenges for Highly Migratory Fish Stocks . Marine Policy

Palma, Mary Ann., Martin Tsamenyi, dan William Edeson, 2010. Promoting Sustainable Fisheries : the International Legal and Policy Framework to Combat Illegal, Unreported and Unregulated Fishing. Leiden : Martinus Nijhoff Publishers. 
Seckinelgin, Hakan, 2006. The Environment and International Politics, International Fisheries, Heidegger and Social Method. New York: Routledge.

Swan, Judith, 2000. Regional Fishery Bodies and Governance: Issues, Actions and Future Directions, FAO Fisheries Circular

Taylor, William W., Michael G. Schechter, and Lois G. Wolfson, 2007.Globalization: Effects on Fisheries Resources. New York: Cambridge University Press 